\title{
No sign of denitrification in a Baltic Sea cyanobacterial bloom
}

\author{
Susanna Hietanen ${ }^{1, *}$, Pia H. Moisander ${ }^{1,2}$, Jorma Kuparinen ${ }^{1, * *}$, Liisa Tuominen ${ }^{1}$ \\ ${ }^{1}$ Finnish Institute of Marine Research, PO Box 33, 00931 Helsinki, Finland \\ ${ }^{2}$ Institute of Marine Sciences, University of North Carolina at Chapel Hill, 3431 Arendell Street, Morehead City, \\ North Carolina 28557, USA
}

\begin{abstract}
Denitrification in sediments is of major importance to the Baltic Sea nitrogen (N) budget. However, little is known about denitrification in the water column in the Baltic. We tested whether denitrification could be active in pelagic cyanobacterial aggregates, commonly found in the Baltic Sea during warm summer months. In these aggregates, anoxic microniches may form. Such microzones suggest a possibility for anaerobic processes, such as denitrification by the heterotrophic bacteria associated with the cyanobacteria. Denitrification and nitrogen $\left(\mathrm{N}_{2}\right)$ fixation in a cyanobacterial bloom were measured on a 3 wk cruise in the Baltic Sea in order to determine whether the Baltic Sea cyanobacterial blooms act as sources or sinks of N. Experimental conditions analogous to formation of anoxic microniches within cyanobacterial aggregates did not activate the denitrification process, even when anoxic conditions prevailed for several hours. Only in 3 cases was denitrification, measured using the ${ }^{15} \mathrm{~N}$-isotope pairing method, detectable, giving rates of 0.8 to $1.8 \mathrm{nmolN}_{2} \mathrm{l}^{-1} \mathrm{~h}^{-1}$. Nitrogen fixation, determined using the acetylene reduction assay, varied from 0.03 to $1.85 \mu \mathrm{mol} \mathrm{N}_{2}$ $\mathrm{l}^{-1} \mathrm{~h}^{-1}$. According to this study, the blooms of $\mathrm{N}_{2}$-fixing cyanobacteria in the Baltic Sea must be seen solely as sources, not sinks for $\mathrm{N}$ in the marine pelagic environment.
\end{abstract}

KEY WORDS: Denitrification $\cdot$ Cyanobacteria $\cdot$ Nitrogen fixation $\cdot$ Baltic Sea

\section{INTRODUCTION}

Cyanobacterial blooms are a common phenomenon in the Baltic Sea during warm summer months. The dominating bloom-forming species are the $\mathrm{N}_{2}$-fixing Aphanizomenon flos-aquae and Nodularia spumigena. Nitrogen fixation of the cyanobacteria blooms in the Baltic has been studied intensively (Lindahl et al. 1980, Lindahl \& Wallström 1985, Moisander et al. 1996, Ohlendieck et al. 2000, Wasmund et al. 2001), while few attempts have been made to follow and quantify the flux of the fixed N. Heiskanen \& Kononen (1994) found no evidence of sedimentation of the gas vacuo-

\footnotetext{
*E-mail: susanna.hietanen@fimr.fi

** Present address: Department of Ecology and Systematics, Division of Hydrobiology, University of Helsinki, PO Box 65, 00014 Helsingin Yliopisto, Finland
}

lated cyanobacterial cells. They concluded that most of the cyanobacteria were decomposed within the surface layer, therefore releasing the fixed $\mathrm{N}$ in surface waters. In the central Baltic Sea, 5 to $10 \%$ of the newly fixed $\mathrm{N}$ during active growth of the filamentous cyanobacteria was incorporated into the picoplanktonic size fraction via exudates (Ohlendieck et al. 2000). The main $\mathrm{N}$ release mechanism was, however, lysis of the cyanobacterial cells as the bloom decayed (Ohlendieck et al. 2000). Grazing on Baltic Sea cyanobacteria has been shown to be of minor importance (e.g. Sellner et al. 1994) and therefore, direct transfer of fixed $\mathrm{N}$ to higher trophic levels is inefficient. In contrast, previous studies have indicated that cyanobacterial blooms support an active microbial community over the whole lifetime of the blooms (Bursa 1968, Hoppe 1981, Heinänen et al. 1995, Worm \& Søndergaard 1998). These microbial interactions with cyanobacteria are not nec- 
essarily signs of decay, since cyanobacteria may provide heterotrophic bacteria a source of labile substrates, while the heterotrophic bacteria provide cyanobacteria a source of remineralised nutrients.

Different types of aggregates in various marine environments have been shown to harbour microenvironments with steep gas and chemical gradients (Paerl 1985, Paerl \& Prufert 1987, Shanks \& Reeder 1993, Ploug et al. 1997). In 1999, we measured respiration (Winkler titration method) in spherical Nodularia spumigena-aggregates (2 to $4 \mathrm{~mm}$ in diameter) in the Gulf of Finland and found respiration rates high enough to create anoxia in the centre of the aggregates during darkness (Hietanen et al. unpubl. data, cf. Ploug et al. 1997). In addition, anoxia inside cyanobacterial aggregates, prevailing up to $12 \mathrm{~h}$, has been directly measured (using microelectrodes) in aggregates of 2 to $5 \mathrm{~mm}$ of diameter in a Baltic Sea bloom $(\mathrm{H}$. Ploug pers. comm.). Such microzones may facilitate localised specialisation of facultatively anaerobic bacteria in anaerobic biogeochemical processes, such as denitrification. In 1999, the presence of bacterial (nirS/K) sequences encoding nitrite reductase, verifying presence of bacteria potentially capable for denitrification, was confirmed both from single aggregates and from cyanobacterial surface scum (J. M. Tuomainen unpubl. data).

The need for substrates formed in oxic conditions and the $\mathrm{O}_{2}$ sensitivity of denitrification enzymes limits the occurrence of denitrification to milieus with steep $\mathrm{O}_{2}$ gradients, such as sediment-water or oxic-anoxic water layer interfaces or, as mentioned above, inside aggregates. Cyanobacteria capable of fixing $\mathrm{N}_{2}$ regularly aggregate during intensive blooms. Nitrogen fix-

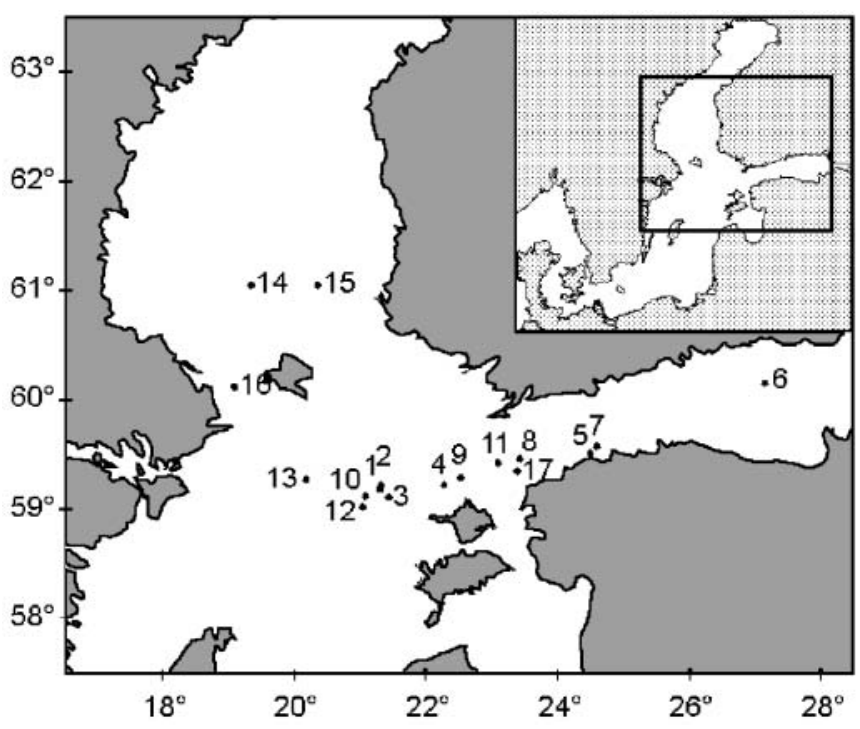

Fig. 1. Sampling stations in the northern Baltic Sea. See Table 1 for further details ation and productivity in filamentous cyanobacteria appear to benefit from low turbulence conditions, which also enhance aggregation (Paerl 1985, Moisander et al. 2002). Aggregates, like sediments, provide both surfaces to colonise and a concentrated source of organic matter to metabolise. Microbial remineralisation of organic matter results in $\mathrm{O}_{2}$-poor microzones around and within particles. Anoxic patches remain even in well-oxygenated surroundings, such as productive surface scums of cyanobacteria, because the physical structure (e.g. mucus) provided by the aggregate slows gas diffusion in and out of the microzone (Shanks \& Reeder 1993). Paerl (1985) and Ploug et al. (1997) also point out the importance of low environmental turbulence in order to establish anoxic conditions inside an aggregate.

From July to August 2000, we followed the N transformation processes in a cyanobacterial bloom in the northern Baltic Sea. The aim of the study was to quantify both $\mathrm{N}_{2}$ fixation and the possible removal of $\mathrm{N}$ from the pelagic ecosystem by denitrification in order to calculate a $\mathrm{N}$ budget for the cyanobacterial blooms in the Baltic Sea in terms of inputs and losses of $N$. The ${ }^{15} \mathrm{~N}$-isotope pairing method (Nielsen 1992) has proven to be an excellent tool in measuring denitrification in sediments (e.g. Lohse et al. 1996, Tuominen et al. 1998). Here, we tested whether it could also be used in measuring potential denitrification in a cyanobacterial bloom. We created incubation conditions in which the $\mathrm{O}_{2}$ concentrations decreased steadily, and monitored the onset of denitrification by following the emergence of ${ }^{29} \mathrm{~N}_{2}$ and ${ }^{30} \mathrm{~N}_{2}$. As denitrification sometimes does not proceed to the end $\left(\mathrm{N}_{2}\right)$ but ceases after reduction of nitrite $\left(\mathrm{NO}_{2}{ }^{-}\right)$to nitrous oxide $\left(\mathrm{N}_{2} \mathrm{O}\right)$ (e.g. Patureau et al. 1994, Frette et al. 1997, Gejlsbjerg et al. 1998), production of $\mathrm{N}_{2} \mathrm{O}$ was also measured. In addition to measuring $\mathrm{N}_{2}$ fixation and denitrification, we also measured bacterial numbers and production to verify that the cyanobacterial bloom indeed supported a high level of heterotrophic microbial activity.

\section{MATERIALS AND METHODS}

Sample preparation. Samples were collected from July to August 2000 onboard the RV 'Aranda' (Finnish Institute of Marine Research) in the northern Baltic Sea area (Fig. 1, Table 1). Wind kept the upper surface layer well mixed to a depth of approximately $20 \mathrm{~m}$; therefore, no visible surface accumulations (cyanobacterial scums) were detected in the study area during the study period despite high chlorophyll a (chl a) values (up to $9 \mu \mathrm{g} \mathrm{l}^{-1}$ ). To simulate a heavy surface bloom, a zooplankton net (100 $\mu \mathrm{m}$ mesh size) was used to collect cyanobacteria from the mixed layer. The resulting 
concentrated phytoplankton suspension was diluted with surface water (1:1) to better reflect the natural cyanobacterial concentration in a surface scum. This 'artificial bloom sample' was then used in the measurements. For chl a measurement, triplicate subsamples of 20 to $50 \mathrm{ml}$ of concentrate were filtered on GF/F filters. Chl a was extracted in $94 \%$ ethanol for $24 \mathrm{~h}$ in room temperature in the dark and then measured fluorometrically (excitation at 580-680 $\mathrm{nm}$, emission at $672 \mathrm{~nm}$ ), 672 nm (Perkin Elmer LS-2) (HELCOM 1988). Averages of the upper mixed layer temperature and salinity were calculated from CTD-casts. Samples for nutrient $\left(\mathrm{PO}_{4}{ }^{3-}, \mathrm{NO}_{3}{ }^{-}, \mathrm{NO}_{2}{ }^{-}, \mathrm{NH}_{4}{ }^{+}\right)$measurements were taken from $1 \mathrm{~m}$ depth and analysed with a Lachat QC8000 autoanalyser using methods based on Grasshoff et al. (1999). $\mathrm{NH}_{4}{ }^{+}$was analysed manually according to Koroleff (1983).

Denitrification. The isotope pairing method is based on adding ${ }^{15} \mathrm{~N}$-isotope in a form of ${ }^{15} \mathrm{NO}_{3}{ }^{-}$and following the emergence of $\mathrm{N}_{2}$ molecules labelled partly $\left({ }^{14} \mathrm{~N}^{15} \mathrm{~N}\right)$ or completely $\left({ }^{15} \mathrm{~N}^{15} \mathrm{~N}\right)$ with the added heavy isotope. Calculating the actual denitrification occurring in nature is based on statistics of the relative abundance of the different fractions (Nielsen 1992).
Glass vials (23 ml) equipped with diagonally cut conical glass stoppers were used, enabling incubations in gas-tight, bubble-free conditions. The experiments were performed using 2 replicates for each 3 time points (oxic, hypoxic and anoxic conditions, see below). $\mathrm{K}^{15} \mathrm{NO}_{3}$ solution (99 atom\%, Europa Scientific) was added to the vials (100 $\mu \mathrm{M}$ final incubation concentration) that were immediately closed and covered in aluminium foil. During incubation at in situ temperature, the samples were slowly rotated in a plankton wheel in order to keep the phytoplankton suspension well mixed (Ploug \& Grossart 1999). The time points at which incubations were terminated were decided based on the respiration measurements done from the parallel samples (see below). The first 2 replicate vials were removed from incubation usually after 2 to $3 \mathrm{~h}$ when the $\mathrm{O}_{2}$ concentration was still high $\left(\sim 100 \mu \mathrm{M} \mathrm{O}_{2}\right)$. The next 2 replicate vials were removed when the conditions in vials were hypoxic $\left(\sim 40 \mu \mathrm{M} \mathrm{O}_{2}\right)$ and the last 2 were incubated until anoxic conditions had prevailed for several hours (Joye \& Paerl 1993, Frette et al. 1997). This design allowed us to follow the onset of denitrification activity as a function of $\mathrm{O}_{2}$ availability. The activity in samples and in 1 blank at the beginning of each incubation was

Table 1. Temperature, salinity and nutrients in the upper mixed layer at the sampling stations. Chlorophyll a (chl a), bacterial carbon production (BCP) and nitrogen fixation of the phytoplankton concentrate used in the experiments. Nitrogen fixation is expressed as $\mu \mathrm{mol} \mathrm{N} \mathrm{m}^{-2} \mathrm{~h}^{-1}$, calculated using the conversion factor 4:1 for moles of ethylene to moles of $\mathrm{N}_{2}$ and phytoplankton concentration factor (see text for details). The samples processed to further detail are shown in bold (see 'Results' for details). nd $=$ not determined

\begin{tabular}{|c|c|c|c|c|c|c|c|c|c|c|c|c|}
\hline Date & $\begin{array}{l}\text { Station } \\
\text { index }\end{array}$ & $\begin{array}{l}\text { Map } \\
\text { code }\end{array}$ & $\begin{array}{l}\text { Temp. } \\
\left({ }^{\circ} \mathrm{C}\right)\end{array}$ & Salinity & $\begin{array}{l}\mathrm{NO}_{3}^{-} \\
(\mathrm{nM})\end{array}$ & $\begin{array}{l}\mathrm{NO}_{2}^{-} \\
(\mathrm{nM})\end{array}$ & $\begin{array}{l}\mathrm{NH}_{4}^{+} \\
(\mathrm{nM})\end{array}$ & $\begin{array}{c}\mathrm{PO}_{4}{ }^{3-} \\
(\mathrm{nM})\end{array}$ & $\begin{array}{l}\text { DIN:DIP } \\
\text { (molar) }\end{array}$ & $\begin{array}{l}\text { Chl } a \\
\left(\mu g l^{-1}\right)\end{array}$ & $\begin{array}{c}\text { BCP } \\
\left(\mu g \mathrm{l}^{-1} \mathrm{~h}^{-1}\right)\end{array}$ & $\begin{array}{c}\mathrm{N}_{2} \text { fixation } \\
\left(\mu \mathrm{mol} \mathrm{m} \mathrm{m}^{-2} \mathrm{~h}^{-1}\right)\end{array}$ \\
\hline $20 \mathrm{Jul}$ & 321 & 1 & 13.3 & 6.45 & 48 & 30 & 162 & 46 & 5.2 & 466 & nd & 13.95 \\
\hline $21 \mathrm{Jul}$ & $\begin{array}{l}322 \\
324\end{array}$ & $\begin{array}{l}1 \\
2\end{array}$ & $\begin{array}{l}13.7 \\
13.5\end{array}$ & $\begin{array}{l}6.61 \\
6.46\end{array}$ & $\begin{array}{r}34 \\
0\end{array}$ & $\begin{array}{r}120 \\
60\end{array}$ & $\begin{array}{l}172 \\
192\end{array}$ & $\begin{array}{l}12 \\
92\end{array}$ & $\begin{array}{r}27.2 \\
2.7\end{array}$ & $\begin{array}{r}610 \\
2303\end{array}$ & $\begin{array}{l}0.31 \\
1.61\end{array}$ & $\begin{array}{l}15.42 \\
24.58\end{array}$ \\
\hline $22 \mathrm{Jul}$ & 325 & 1 & 13.7 & 6.68 & 68 & 42 & 220 & 70 & 4.7 & 578 & 0.17 & 14.73 \\
\hline $23 \mathrm{Jul}$ & 326 & 3 & 14.6 & 6.80 & 10 & 72 & 118 & 44 & 4.5 & 525 & 1.26 & 19.55 \\
\hline $24 \mathrm{Jul}$ & $\begin{array}{l}328 \\
329\end{array}$ & $\begin{array}{l}3 \\
3\end{array}$ & $\begin{array}{l}14.5 \\
15.1\end{array}$ & $\begin{array}{l}6.81 \\
6.83\end{array}$ & $\begin{array}{l}84 \\
22\end{array}$ & $\begin{array}{l}80 \\
68\end{array}$ & $\begin{array}{l}446 \\
170\end{array}$ & $\begin{array}{l}80 \\
54\end{array}$ & $\begin{array}{l}7.6 \\
4.8\end{array}$ & $\begin{array}{l}716 \\
580\end{array}$ & $\begin{array}{l}1.41 \\
0.47\end{array}$ & $\begin{array}{r}\text { nd } \\
35.67\end{array}$ \\
\hline 26 July & 330 & 3 & 15.0 & 6.80 & 24 & 72 & 158 & 36 & 7.1 & 686 & 0.87 & 11.99 \\
\hline $27 \mathrm{Jul}$ & $\begin{array}{l}331 \\
332\end{array}$ & $\begin{array}{l}3 \\
4\end{array}$ & $\begin{array}{l}\mathbf{1 4 . 6} \\
15.4\end{array}$ & $\begin{array}{l}6.80 \\
6.54\end{array}$ & $\begin{array}{r}106 \\
97\end{array}$ & $\begin{array}{r}6 \\
\text { nd }\end{array}$ & $\begin{array}{l}\mathbf{1 2 4} \\
157\end{array}$ & $\begin{array}{l}\mathbf{9 8} \\
73\end{array}$ & $\begin{array}{c}2.4 \\
\text { nd }\end{array}$ & $\begin{array}{l}657 \\
824\end{array}$ & $\begin{array}{l}\mathbf{0 . 9 9} \\
1.21\end{array}$ & $\begin{array}{r}8.93 \\
\text { nd }\end{array}$ \\
\hline 7 Aug & 333 & 5 & 16.1 & 4.60 & 98 & 20 & 248 & 13 & 28.2 & 274 & 0.36 & 2.36 \\
\hline 8 Aug & 334 & 6 & 17.5 & 4.15 & 113 & 53 & 297 & 13 & 35.6 & 277 & 0.39 & 3.81 \\
\hline 9 Aug & $\begin{array}{l}336 \\
337\end{array}$ & $\begin{array}{l}7 \\
8\end{array}$ & $\begin{array}{l}15.0 \\
15.2\end{array}$ & $\begin{array}{l}5.21 \\
6.03\end{array}$ & $\begin{array}{l}230 \\
448\end{array}$ & $\begin{array}{r}65 \\
112\end{array}$ & $\begin{array}{r}380 \\
1934\end{array}$ & $\begin{array}{r}63 \\
248\end{array}$ & $\begin{array}{l}10.7 \\
10.1\end{array}$ & $\begin{array}{l}237 \\
143\end{array}$ & $\begin{array}{l}0.43 \\
0.23\end{array}$ & $\begin{array}{l}2.24 \\
0.30\end{array}$ \\
\hline 10 Aug & $\begin{array}{l}338 \\
339\end{array}$ & $\begin{array}{r}9 \\
10\end{array}$ & $\begin{array}{l}16.1 \\
16.0\end{array}$ & $\begin{array}{l}5.65 \\
6.70\end{array}$ & $\begin{array}{l}88 \\
70\end{array}$ & $\begin{array}{l}45 \\
\text { nd }\end{array}$ & $\begin{array}{r}175 \\
\text { nd }\end{array}$ & $\begin{array}{l}20 \\
\text { nd }\end{array}$ & $\begin{array}{r}15.4 \\
\text { nd }\end{array}$ & $\begin{array}{l}363 \\
305\end{array}$ & $\begin{array}{l}0.94 \\
0.73\end{array}$ & $\begin{array}{l}4.23 \\
5.94\end{array}$ \\
\hline 11 Aug & 340 & 11 & 16.1 & 5.87 & 115 & 48 & 113 & 33 & 8.4 & 197 & 0.30 & 2.05 \\
\hline 12 Aug & $\begin{array}{l}341 \\
342\end{array}$ & $\begin{array}{l}12 \\
13\end{array}$ & $\begin{array}{l}15.7 \\
14.8\end{array}$ & $\begin{array}{l}6.69 \\
6.27\end{array}$ & $\begin{array}{r}18 \\
210\end{array}$ & $\begin{array}{l}40 \\
\text { nd }\end{array}$ & $\begin{array}{r}140 \\
\text { nd }\end{array}$ & $\begin{array}{l}36 \\
\text { nd }\end{array}$ & $\begin{array}{l}5.5 \\
\text { nd }\end{array}$ & $\begin{array}{l}226 \\
325\end{array}$ & $\begin{array}{l}0.56 \\
1.26\end{array}$ & $\begin{array}{l}2.73 \\
4.77\end{array}$ \\
\hline 13 Aug & $\begin{array}{l}343 \\
344\end{array}$ & $\begin{array}{l}14 \\
15\end{array}$ & $\begin{array}{l}12.9 \\
14.0\end{array}$ & $\begin{array}{l}5.56 \\
5.52\end{array}$ & $\begin{array}{r}34 \\
240\end{array}$ & $\begin{array}{l}74 \\
\text { nd }\end{array}$ & $\begin{array}{l}72 \\
\text { nd }\end{array}$ & $\begin{array}{l}18 \\
\text { nd }\end{array}$ & $\begin{array}{r}10.0 \\
\text { nd }\end{array}$ & $\begin{array}{l}262 \\
196\end{array}$ & $\begin{array}{r}0.21 \\
\text { nd }\end{array}$ & $\begin{array}{r}2.26 \\
\text { nd }\end{array}$ \\
\hline 16 Aug & 347 & 16 & 14.6 & 4.79 & 92 & 24 & 520 & 30 & 21.2 & 374 & 0.17 & 0.98 \\
\hline 17 Aug & 348 & 17 & 16.6 & 5.64 & 110 & nd & nd & nd & nd & 302 & 0.70 & 4.10 \\
\hline
\end{tabular}


terminated by carefully adding $2 \mathrm{ml}$ of $\mathrm{ZnCl}_{2}$ solution $\left(500 \mu \mathrm{g} \mathrm{ml}^{-1}\right)$ under the surface, avoiding release of gas from the samples. The samples were then transferred to $10 \mathrm{ml}$ gas-tight Exetainers (Labco) containing $500 \mu \mathrm{l}$ of $\mathrm{ZnCl}_{2}$ solution. The mass ratios of $\mathrm{N}_{2}\left({ }^{28} \mathrm{~N}_{2},{ }^{29} \mathrm{~N}_{2}\right.$ and ${ }^{30} \mathrm{~N}_{2}$ ) formed during incubations and those of the original phytoplankton suspension (for background subtraction) were later analysed using a mass spectrometer by the National Environmental Research Institute in Silkeborg, Denmark. The significance of the changes in mass ratios was evaluated using a $t$-test. Denitrification was only considered to occur in samples in which both ${ }^{15} \mathrm{~N}$-labelled fractions $\left({ }^{29} \mathrm{~N}_{2}\right.$ and $\left.{ }^{30} \mathrm{~N}_{2}\right)$ increased significantly $(\mathrm{p}<0.05)$. Denitrification (as $\mathrm{nmol}_{2}$ formed) was calculated from the differences in isotopic compositions at the end and the beginning of the incubation. The denitrification rate per $\mathrm{h}\left(\mathrm{nmol} \mathrm{N} \mathrm{l}_{2} \mathrm{l}^{-1} \mathrm{~h}^{-1}\right)$, however, was calculated using only the incubation time when anoxic conditions prevailed, as the denitrifying bacteria are facultative anaerobes that switch to denitrification as a form of anaerobic metabolisms when $\mathrm{O}_{2}$ concentration decreases (Tiedje 1988).

$\mathbf{N}_{2} \mathrm{O}$ production measurements. Samples (no replicates) were incubated following the same incubation design as in the denitrification measurements, using 3 time points (sampling at times when oxic, hypoxic and anoxic conditions prevailed). To measure both natural $\mathrm{N}_{2} \mathrm{O}$ production and $\mathrm{N}_{2} \mathrm{O}$ production potential, 2 sample sets were prepared. The 8 ampoules $(23 \mathrm{ml})$ were filled with sample suspension and 4 of the ampoules were then enriched with $\mathrm{KNO}_{3}$ solution to the final concentration of $100 \mu \mathrm{M}$ while the remaining 4 remained at natural nutrient concentrations. Background subtraction blanks ( 1 with and 1 without $\mathrm{KNO}_{3}$ addition) were prepared by adding $250 \mu \mathrm{l}$ formalin before sealing all the ampoules using gas-tight rubber septums and aluminium seal rings (ScherfCroma). During incubation at in situ temperature, the samples were slowly rotated in a plankton wheel. Incubations were terminated at the same time points as the denitrification measurements by injecting $250 \mu \mathrm{l}$ formalin through the septum with an overflow needle inserted. Samples were later analysed for $\mathrm{N}_{2} \mathrm{O}$ at $35^{\circ} \mathrm{C}$ using a Hewlett Packard 5890 series II gas chromatograph equipped with an HP 3396 A integrator, electron capture detector and a Porapak Q column, with an argonmethane $(95: 5 \%)$ mixture as a carrier gas. The concentration of $\mathrm{N}_{2} \mathrm{O}$ in the samples was calculated using the gas equation $(\mathrm{P} \times \mathrm{V}=\mathrm{n} \times \mathrm{R} \times \mathrm{T}$, where $\mathrm{P}$ is pressure, $\mathrm{V}$ is volume, $\mathrm{n}$ is the number of moles of gas, $\mathrm{R}$ is the ideal gas constant, and $\mathrm{T}$ is temperature) and the Ostwald gas absorption coefficient (Weiss \& Price 1980).

Bacterial production and cell numbers. The ${ }^{3} \mathrm{H}$ thymidine incorporation method (Fuhrman \& Azam 1980) was used to measure the heterotrophic bacterial production of the artificial bloom sample. Samples of the concentrate $(5 \mathrm{ml} ; 3$ replicates, 1 formalin-killed blank) were incubated at in situ temperatures in the dark using the tested saturating concentration (ca. $100 \mathrm{nM}$, data not shown) of ${ }^{3} \mathrm{H}$-thymidine (Amersham TRK-637) and incubation time of 20 to $60 \mathrm{~min}$ (tested to be linear, data not shown). Incubations were terminated with formalin and samples extracted on cellulosenitrate filters $(\varnothing 25 \mathrm{~mm}$, pore size $0.2 \mu \mathrm{m}$, Sartorius $)$ (Riemann 1984, Børsheim 1990). Filters were dissolved in scintillation cocktail (Insta-Gel Plus, Packard), shaken vigorously and the radioactivity was counted in a scintillation counter (Wallac Rackbeta 1217). The ratio between incorporated thymidine and cell production varies geographically and among growth conditions. Therefore, a separate experiment was carried out in which the conversion factor for the local microbial community was determined according to Bjørnsen \& Kuparinen (1991) from the slope of regression between cumulative incorporated thymidine and cell number in a batch culture. Bacterial carbon production was calculated using the conversion factor determined $(3.5 \times$ $10^{17}$ cells per mol thymidine incorporated, $\mathrm{r}^{2}=0.90$ ), an average cell volume for the study area and season (0.077 $\mu^{3}{ }^{3}$, Tuomi 1997) and $C$ content measured using X-ray microanalysis for the study area $(0.10 \mathrm{pg} \mathrm{C}$ $\mu \mathrm{m}^{-3}$, Fagerbakke et al. 1996).

Formalin-fixed heterotrophic bacteria in the concentrate were counted using DAPI staining and epifluorescence microscopy (Porter \& Feig 1980). Samples were treated with $10 \mathrm{nM}$ pyrophosphate (final concentration) and sonicated in an ultrasonic bath (Bransonic 3200, Branson Ultrasonics) for $20 \mathrm{~min}$ in order to detach the attached bacteria from cyanobacterial filaments (Velji \& Albright 1986). Samples were then diluted 125- to 250-fold, stained at $5 \mu \mathrm{g} \mathrm{ml}^{-1}$ DAPI final concentration (Schallenberg et al. 1989) and filtered on black polycarbonate filters $(\varnothing 25 \mathrm{~mm}$, pore size $0.2 \mu \mathrm{m}$, Poretics). Cells were counted using a Leitz Aristoplan epifluorescence microscope equipped with a UV filter.

Community respiration. Decline of $\mathrm{O}_{2}$ concentration in the artificial bloom sample during the incubation was measured using the Winkler titration method (Winkler 1888). Four replicate samples were used for the start point concentration measurement and 4 replicates were incubated at in situ temperature in the dark for the measurement of the community respiration. Samples in volume calibrated, approximately $11 \mathrm{ml}$ vials were slowly rotated in a plankton wheel during the incubation (90 to $150 \mathrm{~min}$ ). The linearity of $\mathrm{O}_{2}$ decrease was tested twice during the cruise and the respiration was found to be linear for at least $6 \mathrm{~h}$, down to $80 \mu \mathrm{M} \mathrm{O}_{2}$ (data not shown). Results from respiration measurements were used to adjust the incubation times for denitrification and $\mathrm{N}_{2} \mathrm{O}$ production samples (see above). 
Nitrogen fixation. Nitrogen fixation was measured using the acetylene reduction assay (Burris 1972). Quadruplicate $90 \mathrm{ml}$ 'artificial bloom' samples were incubated under $9 \mathrm{ml}$ acetylene in $117 \mathrm{ml}$ serum vials sealed with red rubber stoppers. Triplicate blanks (deionised water) were included for each measurement. Incubation was carried out under slow rotating motion under a constant low light level (approximately $50 \mu \mathrm{mol} \mathrm{m} \mathrm{m}^{-2} \mathrm{~s}^{-1}$ ) at in situ temperature. At the end of the incubation, air phase from each serum vial was sampled into Vacutainer (Beckton Dickinson) tubes. Ethylene measurements on the Vacutainer contents were made at $200^{\circ} \mathrm{C}$ using a Shimadzu GC-9A gas chromatograph equipped with a flame ionisation detector and at $80^{\circ} \mathrm{C}$ using a Porapak $\mathrm{T}$ stainless steel column with $\mathrm{N}_{2}$ as a carrier gas. Moles of ethylene produced were divided by 4 to convert to moles of $\mathrm{N}_{2}$ fixed (Schwintzer \& Tjepkema 1994). To compare the $\mathrm{N}_{2}$ fixation rates with earlier measurements from the Baltic Sea, the rates per 1 were converted to rates per $\mathrm{m}^{2}$ of unconcentrated surface water. The conversion was made based on the net opening, tow depth, number of tows and upper mixed layer depths estimated from CTD casts made at each sampling site. Relatedness of $\mathrm{N}_{2}$ fixation (values per l) with chl a and DIN:DIP ratio was examined by using a Pearson correlation analysis (SPSS for Windows 9.0). Data were $\log _{10}(1+$ value $)$ transformed before analyses to satisfy the normality assumption.

\section{RESULTS}

\section{Denitrification and $\mathrm{N}_{2} \mathrm{O}$ production}

In the 23 samples studied, both increase and decrease of the heavier isotopes were detected. In some samples, increase in one fraction and decrease in the other were measured, showing the limits of the method in such a low activity environment. Only in 3 cases could a significant increase $(t$-test, $\mathrm{p}<0.05)$ be detected at the same time in both isotopic fractions
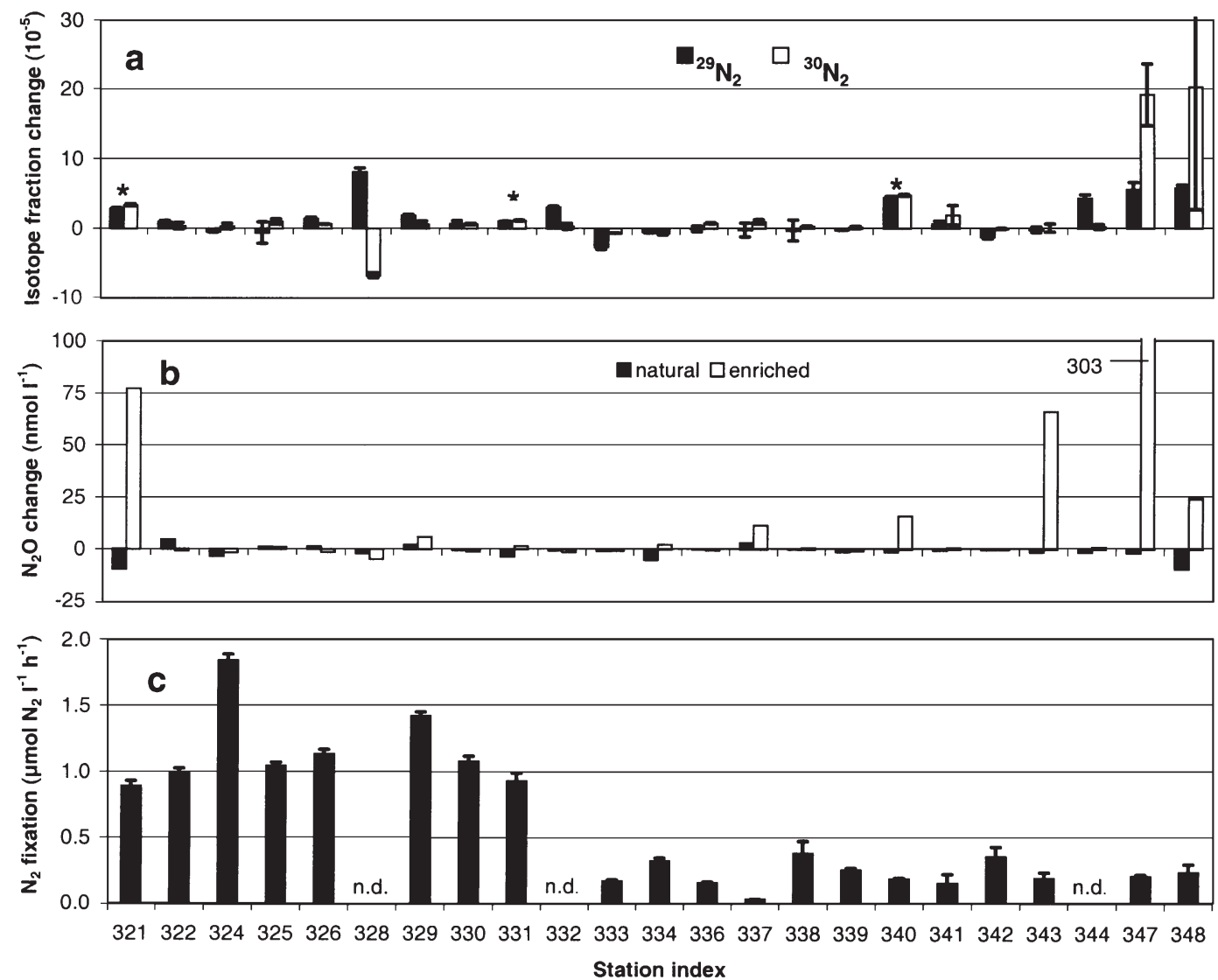

Fig. 2. (a) Changes in the relative abundance of heavier isotopes of the total $\mathrm{N}_{2}$ in the samples. Significant increases compared to the initial situation ( $t$-test, $\mathrm{p}<0.05)$ are marked with an asterisk. Error bars show range of values $(\mathrm{n}=2)$. (b) Changes in $\mathrm{N}_{2} \mathrm{O}$ concentration ( $\mathrm{nmol} \mathrm{l}^{-1}$ ) compared to the initial situation. Enriched samples, incubation concentration $100 \mu_{\mathrm{M} \mathrm{NO}}^{-}$; natural samples, incubation concentration $0.1 \mu \mathrm{M} \mathrm{NO}_{3}^{-}$. (c) $\mathrm{N}_{2}$ fixation $\left(\mu \mathrm{mol} \mathrm{N} \mathrm{N}^{-1} \mathrm{~h}^{-1}\right)$. Error bars show standard deviation $(\mathrm{n}=3)$ 
(Fig. 2a) and the results of these 3 samples were calculated further. On the 3 occasions out of 23 (Indices 321, $331,340)$ when calculating denitrification was meaningful, the rate based on the added ${ }^{15} \mathrm{NO}_{3}{ }^{-}$varied between 1.3 and $3.9 \mathrm{nmol} \mathrm{N}_{2} \mathrm{l}^{-1} \mathrm{~h}^{-1}$, whereas the rate based on naturally occurring ${ }^{14} \mathrm{NO}_{3}{ }^{-}$varied between 0.8 and $1.8 \mathrm{nmol} \mathrm{N}_{2} \mathrm{l}^{-1} \mathrm{~h}^{-1}$ (Fig. 3).

In addition to formation of $\mathrm{N}_{2}$ as the end product of the denitrification reaction series, the changes in $\mathrm{N}_{2} \mathrm{O}$ concentration, a side product of nitrification and an intermediate product of denitrification, were measured. The amount of $\mathrm{N}_{2} \mathrm{O}$ slightly decreased during incubation in most cases, but a clear increase was noticed in
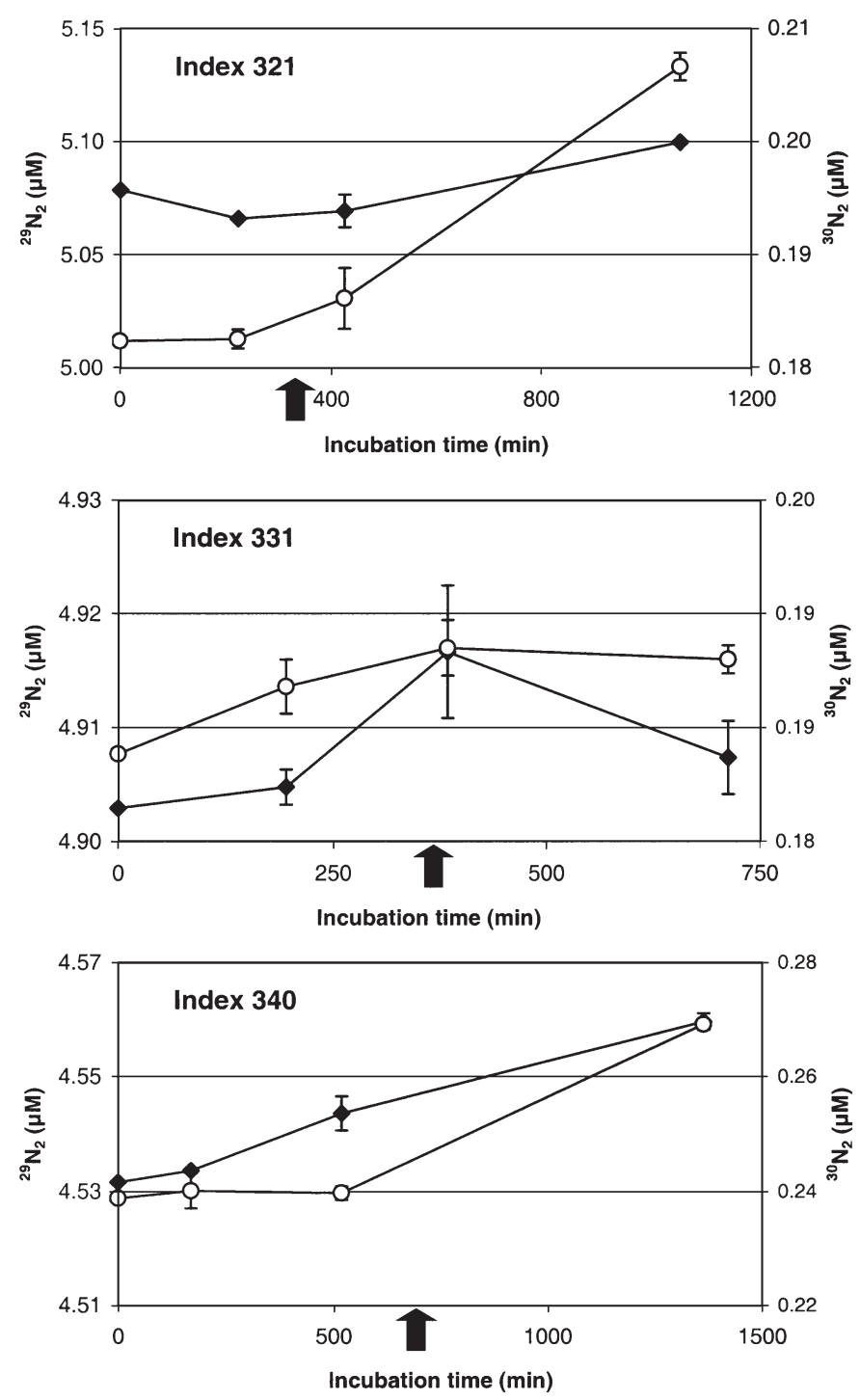

Fig. 3. The average ${ }^{29} \mathrm{~N}_{2}$ and ${ }^{30} \mathrm{~N}_{2}\left(\mu \mathrm{mol} \mathrm{l} \mathrm{l}^{-1}\right)$ of the 2 replicate measurements in the samples showing significant change $(t$-test, $\mathrm{p}<0.05)$ during incubations. $(\bullet){ }^{29} \mathrm{~N}_{2}$ ( $(O){ }^{30} \mathrm{~N}_{2}$. Error bars show range of values $(n=2)$. The arrows show beginning of anoxia
6 out of 23 measurements when the sample was enriched with $\mathrm{NO}_{3}{ }^{-}$(Fig. 2b). The $\mathrm{N}_{2} \mathrm{O}$ production rates varied between -0.55 and $0.39 \mathrm{nmol} \mathrm{l}^{-1} \mathrm{~h}^{-1}$ in the natural samples and between -0.41 and $12.48 \mathrm{nmol} \mathrm{l}^{-1} \mathrm{~h}^{-1}$ in the enriched samples. In the 3 above-mentioned samples the natural $\mathrm{N}_{2} \mathrm{O}$ production rate varied from -0.55 to $-0.05 \mathrm{nmol} \mathrm{l}^{-1} \mathrm{~h}^{-1}$ and in the enriched samples from 0.13 to $4.40 \mathrm{nmol}^{-1} \mathrm{~h}^{-1}$.

\section{Bacterial production and cell numbers}

Thymidine incorporation rates varied from 61 to $597 \mathrm{pmol} \mathrm{l}^{-1} \mathrm{~h}^{-1}$ resulting in heterotrophic $\mathrm{C}$ production of 0.17 to $1.61 \mathrm{\mu g} \mathrm{C}^{-1} \mathrm{~h}^{-1}$ (Table 1). Cell numbers varied from $5.4 \times 10^{7}$ to $3.6 \times 10^{8} \mathrm{ml}^{-1}$.

\section{Nitrogen fixation and phytoplankton}

Nitrogen fixation varied from 0.03 to $1.84 \mu \mathrm{mol} \mathrm{N} \mathrm{l}^{-1}$ $\mathrm{h}^{-1}$ in the phytoplankton concentrate (Fig. 2). The coefficient of variation (CV\%) for the measurements from replicate flasks was from 2.2 to $44 \%$, but remained $<10 \%$ most of the time. Nitrogen fixation rates were the highest (from 0.89 to $1.84 \mu \mathrm{mol} \mathrm{N}_{2} \mathrm{l}^{-1} \mathrm{~h}^{-1}$ ) during the first part of the study period (until July 27) and were reduced to a lower level (from 0.03 to 0.36 $\mu \mathrm{molN} \mathrm{N}_{2} \mathrm{l}^{-1} \mathrm{~h}^{-1}$ ) during the second half. Nitrogen fixation had a strong positive relationship with chl a $(\mathrm{r}=$ 0.908, $\mathrm{p}=0.000$; Pearson correlation) and a negative relationship with the ratio of dissolved inorganic nutrients (DIN:DIP, Table 1) ( $\mathrm{r}=-0.524, \mathrm{p}=0.031$; Pearson correlation). $\mathrm{N}_{2}$ fixation rates per $\mathrm{m}^{2}$ varied from 0.3 to $35.7 \mu \mathrm{mol} \mathrm{N}_{2} \mathrm{~m}^{-2} \mathrm{~h}^{-1}$ (Table 1). Microscopical analyses (data not shown) showed that the dominant phytoplankton in the samples were the $\mathrm{N}_{2}$-fixing cyanobacteria Aphanizomenon sp. and Nodularia sp. (present in lower densities than Aphanizomenon). Anabaena spp. were present only in a few samples. The densities of all of these cyanobacteria decreased towards the end of the study period. Other phytoplankton in the samples formed minor proportions of the total biomass.

\section{DISCUSSION}

\section{Denitrification and $\mathrm{N}_{2} \mathrm{O}$ production}

In the experiments, it was necessary to use net-concentrated cyanobacterial biomass instead of natural aggregates as the sampling period was windy and therefore no aggregates formed despite high cyanobacterial biomass. The chl a content of the concentrate ranged from 143 to $2300 \mu \mathrm{g}^{-1}$ (Table 1), which is sev- 
eral orders of magnitude higher than naturally occurring concentrations during cyanobacterial blooms in the Baltic. Although even up to $18 \mu \mathrm{g} \mathrm{l}^{-1} \mathrm{chl}$ a concentrations have been reported (Heinänen et al. 1995), a more usual value is between 2 and $7 \mathrm{gg} \mathrm{l}^{-1}$ (Heinänen \& Kuparinen 1992, Heinänen et al. 1995, Wasmund et al. 2001). Usually the reported values reflect the integrated chl a values in the whole mixed surface layer. Here, we wanted to simulate the conditions in the uppermost surface layer, a cyanobacterial surface 'scum' in calm conditions; more specifically, the conditions experienced by attached bacteria inside cyanobacterial aggregates. The zooplankton community in the concentrated sample was likely to be different from a natural community because the $100 \mu \mathrm{m}$ mesh selectively collected large zooplankton, allowing smaller grazers to pass through. Herbivore-enhanced nutrient and $\mathrm{C}$ release along with reduced grazing pressure on heterotrophic bacteria most likely favoured the growth of bacteria in the concentrated samples. However, for purposes of measuring activities of cyanobacteria $\left(\mathrm{N}_{2}\right.$ fixation) and attached bacteria ( $\mathrm{N}$ transformations, bacterial production), the concentrate gave a reasonable simulation of a cyanobacterial aggregate. Dissolved $\mathrm{O}_{2}$ decreased linearly to at least $80 \mu \mathrm{M}$ over a period of time ranging from 5 to $14 \mathrm{~h}$ within different experiments. This allowed us to monitor the onset of anaerobic processes in a system analogous to natural formation of anoxic microniches.

In environments with rapidly changing $\mathrm{O}_{2}$ conditions, such as intertidal microbial mats and wastewater treatment plants, denitrification has been shown to begin within hours of the system becoming anoxic (Joye \& Paerl 1993, Frette et al. 1997). However, even though we incubated our samples on average for $10 \mathrm{~h}$ after reaching anaerobic conditions, we did not find any sign of denitrification, with the exception of extremely low rates in 3 samples out of the 23 studied. In the 3 cases where denitrification could be calculated, the rate was approximately $1.3 \mathrm{nmolN}_{2} \mathrm{l}^{-1} \mathrm{~h}^{-1}$. Denitrification at the oxic-anoxic interface of the Baltic Sea deep waters has been estimated to be within the same range $\left(2.1 \mathrm{nmol} \mathrm{N}_{2} \mathrm{l}^{-1} \mathrm{~h}^{-1}\right.$ : Rönner \& Sörensson 1985; $0.9 \mathrm{nmol} \mathrm{N} \mathrm{l}^{-1} \mathrm{~h}^{-1}$ : Brettar \& Rheinheimer 1992), whereas the activity in sediments in the area varies from 3 to $13.5 \mu \mathrm{molN}_{2} \mathrm{~m}^{-2} \mathrm{~h}^{-1}$ (Tuominen et al. 1998). We did not observe any increase in the $\mathrm{N}_{2} \mathrm{O}$ concentration, which could have indicated incomplete denitrification (except in 6 enriched samples). Comparison of the measured denitrification rates with the simultaneously measured $\mathrm{N}_{2}$ fixation rates, 0.03 to $1.84 \mu \mathrm{mol} \mathrm{N}_{2}$ $\mathrm{l}^{-1} \mathrm{~h}^{-1}$, demonstrates that even with unnaturally long anoxic conditions prevailing for the denitrification, cyanobacterial blooms acted as a source, not a sink for $\mathrm{N}$ in the aquatic ecosystem.
Denitrification is controlled by several factors, the most important of which are the availability of $\mathrm{NO}_{3}^{-}$ and organic $\mathrm{C}$, and the absence of $\mathrm{O}_{2}$. Many studies have confirmed that the substrate $\left(\mathrm{NO}_{3}\right.$ and $\left.\mathrm{C}\right)$ availability plays a more important role than the $\mathrm{O}_{2}$ status. It has also been suggested that denitrification in natural marine environments such as in sediments and oxic-anoxic interfaces of deep waters may be limited by C availability (Tiedje et al. 1982, Rönner \& Sörensson 1985, Brettar \& Rheinheimer 1992, Joye \& Paerl 1993). In our samples, $\mathrm{NO}_{3}^{-}$limitation can be ruled out because we added $\mathrm{NO}_{3}{ }^{-}$at the level of $100 \mu \mathrm{M}$ (natural $\mathrm{NO}_{3}{ }^{-}$concentrations were around $0.1 \mu \mathrm{M}$ ). The possible denitrifiers were also not likely to be limited by $\mathrm{C}$ availability, because the fresh and decaying phytoplankton provided a rich source of dissolved organic compounds. The aggregate-attached bacteria were shown to harbour genetic potential for denitrification (J. M. Tuomainen unpubl. data) and the slow emergence of activity in our samples during extended anoxia shows that the bacteria were capable of switching to denitrification as a form of anaerobic metabolism. However, even though optimal conditions prevailed in the incubations, denitrification could only be detected in 3 samples at very low rates after prolonged anoxia, a condition not likely to occur in aggregates in nature (Ploug et al. 1997). Presumably the energy demanding synthesis of denitrification enzymes is not induced in aggregate-attached bacteria in nature because the frequency and magnitude of favourable conditions (anoxia only during the night, in limited microniches) is low compared to the occurrence of oxic conditions.

\section{Bacterial production and cell numbers}

Active metabolism of the aggregate-colonising bacteria is a prerequisite both for formation of anoxic microniches in natural aggregates, and for denitrification. The net-haul sampling, using a $100 \mu \mathrm{m}$ mesh, was not likely to enrich the free-living bacteria in the samples and it is logical to assume that the high number of bacteria in the samples is a result of them being attached to the collected cyanobacteria. The measured bacterial activity, consequently, relates mainly to the attached instead of the free-living community. According to several studies, the attached bacteria, on a cellular basis, are metabolically more active than the free-living bacteria (Alldredge \& Gotschalk 1990, Smith et al. 1992, Grossart et al. 1998, Worm \& Søndergaard 1998). However, some results suggest that bacteria attached to marine snow do not grow any faster than the free-living bacteria (Alldredge et al. 1986, Simon et al. 1990, Worm et al. 2001). In our sam- 
ples, both the thymidine incorporation and the cell numbers were 10 to 20 times higher than measured for the free-living bacterioplankton in the same area (Heinänen 1991, Heinänen \& Kuparinen 1991, Tuomi 1997). Hence, although the filaments were heavily colonised by bacteria, on the cellular basis, the activity of the attached bacteria did not differ from the freeliving bacterioplankton activity.

The thymidine incorporation was positively correlated with chl a concentration, which might be a sign of the cyanobacteria dominating the incorporation. However, no thymidine incorporation was detected in axenic cultures of Nodularia spp. and Aphanizomenon spp., the dominating species in our samples (Lehtimäki et al. 1997, Hietanen et al. 2002). The correlation more likely indicated close coupling between autotrophic and heterotrophic production in the samples. In ageing aggregates, senescent algae might not alone be able to provide a sufficient amount of degradable material for the maintenance of high standing stock of attached bacteria. Therefore, the role of 'recycling' of organic matter from microzooplankton (as excretion, dead cells, fecal pellets, sloppy feeding) to bacteria is emphasised as the aggregates get older (Hoppe 1981, Taylor et al. 1986, Biddanda \& Pomeroy 1988). Cyanobacterial aggregates can stay in the upper water layer for weeks because of their buoyancy and reach a steady state in which in- and output of organic matter is balanced (Hoppe 1981).

\section{Nitrogen fixation}

The goal of the $\mathrm{N}_{2}$ fixation measurements in this study was to compare the changes and relative magnitude in $\mathrm{N}_{2}$ fixation ( $\mathrm{N}$ inputs) with $\mathrm{N}$ losses through denitrification in the cyanobacterial bloom. The result of these comparisons was clear: the $\mathrm{N}_{2}$ fixation rates were 3 to 4 orders of magnitude higher than the highest denitrification rates. Temporal comparisons of rates were not possible due to overall low or absent denitrification. The $\mathrm{N}_{2}$ fixation rates measured were within the range of previously published rates from the Baltic Sea (Lindahl et al. 1980, Lindahl \& Wallström 1985, Niemistö et al. 1989, Kononen et al. 1999). Maximum $\mathrm{N}_{2}$ fixation rates of approximately 5 -fold (Niemistö et al. 1989) as well as half the ones measured here (Kononen et al. 1999) have been reported from the Baltic Sea. When comparing these results to previous studies, one has to bear in mind that the conversion factor from ethylene to $\mathrm{N}_{2}$ (4:1 mol used in this study) can vary in natural conditions (Moisander et al. 1996, Kononen et al. 1999). The values presented here are likely to represent an underestimate of the highest potential $\mathrm{N}_{2}$ fixation rates in the system. This is because (1) because some of the cyanobacteria pass the $100 \mu \mathrm{m}$ mesh net used in sample collection; (2) lower light levels were used during the incubations than the cyanobacteria would experience in the natural conditions; and (3) the artificial concentration of cyanobacteria using a plankton net may have negative effects (Leonardson 1983, Moisander et al. 1996).

Nitrogen fixation per volume was strongly coupled with chl $a$ concentration, which is expected if $\mathrm{N}_{2}$-fixing cyanobacteria are dominating the community. This was confirmed with microscopy and therefore, the chl a values gave a good estimate of densities of $\mathrm{N}_{2}$-fixing cyanobacteria. Microscopical analyses showed that densities of $\mathrm{N}_{2}$-fixers decreased towards the end of the study period, causing the reduction in $\mathrm{N}_{2}$ fixation. The negative relationship between DIN:DIP and $\mathrm{N}_{2}$ fixation suggests that the change in nutrient availabilities towards the end of the study period may have led to reduced growth of the $\mathrm{N}_{2}$-fixers (Niemi 1979).

\section{CONCLUSIONS}

These experiments confirmed that the cyanobacterial filaments were colonised by heterotrophic bacteria and that these bacteria were actively growing. Conditions analogous to formation of anoxic microniches within cyanobacterial aggregates did not trigger a switch to denitrification as a form of anaerobic metabolism, even when anoxic conditions prevailed for several hours. Therefore, it is unlikely that denitrification plays any significant role in Baltic Sea $\mathrm{N}_{2}$-fixing cyanobacterial blooms in which anoxic microzones may be present only fleetingly (Ploug et al. 1997). According to these results, the filamentous $\mathrm{N}_{2}$-fixing cyanobacteria must be seen solely as a source and not as a sink for N in the Baltic Sea.

Acknowledgements. This study was supported by grants from the Maj and Tor Nessling Foundation (S. H.) and Academy of Finland (P. M.). Sari Leiniö composed the map, Susanna Hyvärinen analysed the chlorophyll samples, Ilkka Lastumäki and Pirkko Lemponen analysed the nutrients, and Tero Purokoski provided us with the CTD data, all of which is gratefully acknowledged. A big thank-you is due to Dr. Asko Simojoki from the Department of Applied Chemistry and Microbiology (University of Helsinki) for help with the gas chromatograph for $\mathrm{N}_{2} \mathrm{O}$ analyses. The comments of 4 anonymous reviewers significantly improved the manuscript.

\section{LITERATURE CITED}

Alldredge AL, Gotschalk CC (1990) The relative contribution of marine snow of different origins to biological processes in coastal waters. Cont Shelf Res 10:41-58

Alldredge AL, Cole JJ, Caron DA (1986) Production of heterotrophic bacteria inhabiting macroscopic organic ag- 
gregates (marine snow) from surface waters. Limnol Oceanogr 31:68-78

Biddanda BA, Pomeroy LR (1988) Microbial aggregation and degradation of phytoplankton-derived detritus in seawater. I. Microbial succession. Mar Ecol Prog Ser 42:79-88

Bjørnsen PK, Kuparinen J (1991) Determination of bacterioplankton biomass, net production and growth efficiency in the Southern Ocean. Mar Ecol Prog Ser 71:185-194

Børsheim KY (1990) Bacterial biomass and production rates in Gulf Stream front regions. Deep-Sea Res Part A 8:1297-1309

Brettar I, Rheinheimer G (1992) Influence of carbon availability on denitrification in the central Baltic Sea. Limnol Oceanogr 37:1146-1163

Burris RH (1972) Measurement of biological $\mathrm{N}_{2}$ fixation with ${ }^{15} \mathrm{~N}_{2}$ and acetylene. In: Sorokin YI, Kadota H (eds) Techniques for the assessment of microbial production and decomposition in fresh waters. IBP Handbook 23. Blackwell Scientific, Oxford, p 3-14

Bursa AS (1968) Epicenoses on Nodularia spumigena Mertens in the Baltic Sea. Acta Hydrobiol 10:267-297

Fagerbakke KM, Heldal M, Norland S (1996) Content of carbon, nitrogen, oxygen, sulfur and phosphorus in native aquatic and cultured bacteria. Aquat Microb Ecol 19: $15-27$

Frette L, Gejlsbjerg B, Westermann P (1997) Aerobic denitrifiers isolated from an alternating activated sludge system. FEMS Microbiol Ecol 24:363-370

Fuhrman JA, Azam F (1980) Bacterioplankton secondary production estimates for coastal waters of British Columbia, Antarctica, and California. Appl Environ Microbiol 39: 1085-1095

Gejlsbjerg B, Frette L, Westermann P (1998) Dynamics of $\mathrm{N}_{2} \mathrm{O}$ production from activated sludge. Water Res 32: 2113-2121

Grasshoff K, Kremling K, Ehrhardt M (1999) Methods of seawater analysis, 3rd edn. Wiley-VCH, Weinheim

Grossart HP, Berman T, Simon M, Pohlmann K (1998) Occurrence and microbial dynamics of macroscopic organic aggregates (lake snow) in Lake Kinneret, Israel, in fall. Aquat Microb Ecol 14:59-67

Heinänen A (1991) Bacterial numbers, biomass and productivity in the Baltic Sea: a cruise study. Mar Ecol Prog Ser 70:283-290

Heinänen A, Kuparinen J (1991) Horizontal variation of bacterioplankton in the Baltic Sea. Appl Environ Microbiol 57: 3150-3155

Heinänen A, Kuparinen J (1992) Response of bacterial thymidine and leucine incorporation to nutrient $\left(\mathrm{NH}_{4}, \mathrm{PO}_{4}\right)$ and carbon (sucrose) enrichment. Arch Hydrobiol Beih Ergebn Limnol 37:241-251

Heinänen A, Kononen K, Kuosa H, Kuparinen J, Mäkelä K (1995) Bacterioplankton growth associated with physical fronts during a cyanobacterial bloom. Mar Ecol Prog Ser 116:233-245

Heiskanen AS, Kononen K (1994) Sedimentation of vernal and late summer phytoplankton communities in the coastal Baltic Sea. Arch Hydrobiol 131:175-198

HELCOM (1988) Guidelines for the Baltic Monitoring Programme for the 3rd stage. Part D. Biological determinands. Baltic Sea Environment Proceedings 27 D:1-161, Helsinki

Hietanen S, Lehtimäki J, Tuominen L, Sivonen K, Kuparinen J (2002) Nodularia sp. (Cyanobacteria) incorporate leucine but not thymidine; importance for bacterial production measurements. Aquat Microb Ecol 28:99-104

Hoppe HG (1981) Blue-green algae agglomeration in surface water: a microbiotope of high bacterial activity. Kieler Meeresforsch Sonderh 5:291-303

Joye SB, Paerl HW (1993) Contemporaneous nitrogen fixation and denitrification in intertidal microbial mats: rapid response to runoff events. Mar Ecol Prog Ser 94:267-274

Kononen KM, Huttunen M, Kanoshina I, Laanemets J, Moisander P, Pavelson J (1999) Spatial and temporal variability of a dinoflagellate-cyanobacterium community under a complex hydrodynamical influence: a case study at the entrance to the Gulf of Finland. Mar Ecol Prog Ser 186: $43-57$

Koroleff F (1983) Determination of ammonia. In: Grasshoff K, Ehrhardt M, Kremling K (eds) Methods of seawater analysis, 2nd edn. Verlag Chemie, Weinheim, p 150-157

Lehtimäki J, Moisander P, Sivonen K, Kononen K (1997) Growth, nitrogen fixation, and nodularin production by two Baltic Sea cyanobacteria. Appl Environ Microbiol 63: $1647-1656$

Leonardson L (1983) Effects of concentrating phytoplankton on the acetylene-reduction assay for nitrogenase activity. Freshw Biol 13:265-274

Lindahl G, Wallström K (1985) Nitrogen fixation (acetylene reduction) in planktonic cyanobacteria in Öregrundsgrepen, SW Bothnian Sea. Arch Hydrobiol 104:193-204

Lindahl G, Wallström K, Brattberg G (1980) Short-term variations in nitrogen fixation in a coastal area of northern Baltic. Arch Hydrobiol 89:88-100

Lohse L, Kloosterhuis HT, van Raaphorst W, Helder W (1996) Denitrification rates as measured by the isotope pairing method and by the acetylene inhibition technique in continental shelf sediments of the North Sea. Mar Ecol Prog Ser 132:169-179

Moisander P, Lehtimäki J, Sivonen K, Kononen K (1996) Comparison of ${ }^{15} \mathrm{~N}_{2}$ and acetylene reduction methods for the measurement of nitrogen fixation by Baltic Sea cyanobacteria. Phycologia 35(Suppl 6):140-146

Moisander PH, Hench JL, Kononen K, Paerl HW (2002) Smallscale shear effects on heterocystous cyanobacteria. Limnol Oceangr 47:108-119

Nielsen LP (1992) Denitrification in sediment determined from nitrogen isotope pairing. FEMS Microbiol Ecol 86: $357-362$

Niemi Å (1979) Blue-green algal blooms and N:P ratio in the Baltic Sea. Acta Bot Fenn 110:57-62

Niemistö L, Rinne I, Melvasalo T, Niemi Å (1989) Blue-green algae and their nitrogen fixation in the Baltic in 1980, 1982 and 1984. Meri 17:1-59

Ohlendieck U, Stuhr A, Siegmund H (2000) Nitrogen fixation by diazotrophic cyanobacteria in the Baltic Sea and transfer of the newly fixed nitrogen to picoplankton organisms. J Mar Syst 25:213-219

Paerl HW (1985) Microzone formation: its role in the enhancement of aquatic $\mathrm{N}_{2}$ fixation. Limnol Oceanogr 30: $1246-1252$

Paerl HW, Prufert LE (1987) Oxygen-poor microzones as potential sites of microbial $\mathrm{N}_{2}$ fixation in nitrogendepleted aerobic marine waters. Appl Environ Microbiol 53:1078-1087

Patureau D, Davison J, Bernet N, Moletta R (1994) Denitrification under various aeration conditions in Comamonas sp., strain SGLY2. FEMS Microb Ecol 14:71-78

Ploug H, Grossart HP (1999) Bacterial production and respiration in suspended aggregates - a matter of the incubation method. Aquat Microb Ecol 20:21-29

Ploug H, Kühl M, Buchholz-Cleven B, Jørgensen BB (1997) Anoxic aggregates - an ephemeral phenomenon in the pelagic environment? Aquat Microb Ecol 13:285-294 
Porter KG, Feig YS (1980) The use of DAPI for identifying and counting aquatic microflora. Limnol Oceanogr 25:943-948

Riemann B (1984) Determining growth rates of natural assemblages of freshwater bacteria by means of ${ }^{3} \mathrm{H}$-thymidine incorporation into DNA: comments on methodology. Arch Hydrobiol Beih Ergebn Limnol 19:76-80

Rönner U, Sörensson F (1985) Denitrification rates in the lowoxygen waters of the stratified Baltic Proper. Appl Environ Microbiol 50:801-806

Schallenberg M, Kalff J, Rasmussen JB (1989) Solutions to problems in enumerating sediment bacteria by direct counts. Appl Environ Microbiol 55:1214-1219

Schwintzer CR, Tjepkama JD (1994) Factors affecting the acetylene to ${ }^{15} \mathrm{~N}_{2}$ conversion ratio in root nodules of Myrica gale L. Plant Physiol 106:1041-1047

Sellner KG, Olson MM, Kononen K (1994) Copepod grazing in a summer cyanobacteria bloom in the Gulf of Finland. Hydrobiologia 292/293:249-254

Shanks AL, Reeder ML (1993) Reducing microzones and sulfide production in marine snow. Mar Ecol Prog Ser 96: 43-47

Simon M, Alldredge AL, Azam F (1990) Bacterial carbon dynamics on marine snow. Mar Ecol Prog Ser 65:205-211

Smith DC, Simon M, Alldredge AL, Azam F (1992) Intense hydrolytic enzyme activity on marine aggregates and implications for rapid particle dissolution. Nature 359: 139-142

Taylor GT, Karl DM, Pace ML (1986) Impact of bacteria and zooflagellates on the composition of sinking particles: an in situ experiment. Mar Ecol Prog Ser 29:141-155

Tiedje JM (1988) Ecology of denitrification and dissimilatory nitrate reduction to ammonium. In: Zehnder AJB (ed) Bio-

Editorial responsibility: Otto Kinne (Editor),

Oldendorf/Luhe, Germany logy of anaerobic microorganisms. Wiley-Liss, New York, p 180-244

Tiedje JM, Sexstone AJ, Myrold DD, Robinson JA (1982) Denitrification: ecological niches, competition and survival. Antonie van Leeuwenhoek J Microbiol 48:569-583

Tuomi P (1997) Bacterial carbon production in the northern Baltic: a comparison of thymidine incorporation and FDC based methods. Mar Ecol Prog Ser 153:59-66

Tuominen L, Heinänen A, Kuparinen J, Nielsen LP (1998) Spatial and temporal variability of denitrification in the sediments of the northern Baltic Proper. Mar Ecol Prog Ser 172:13-24

Velji M, Albright LJ (1986) Microscopic enumeration of attached marine bacteria of seawater, marine sediment, fecal matter, and kelp blade samples following pyrophosphate and ultrasound treatments. Can J Microbiol 32: 121-126

Wasmund N, Voss M, Lochte K (2001) Evidence of nitrogen fixation by non-heterocystous cyanobacteria in the Baltic Sea and re-calculation of a budget of nitrogen fixation. Mar Ecol Prog Ser 214:1-14

Weiss RF, Price BA (1980) Nitrous oxide solubility in water and seawater. Mar Chem 8:347-359

Winkler LW (1888) Die Bestimmung des im Wasser gelösten Sauerstoffes. Ber Dtsch Chem Ges 24:3602-3610

Worm J, Søndergaard M (1998) Dynamics of heterotrophic bacteria attached to Microcystis spp. (Cyanobacteria). Aquat Microb Ecol 14:19-28

Worm J, Gustavson K, Garde K, Broch NH, Søndergaard M (2001) Functional similarity of attached and free-living bacteria during freshwater phytoplankton blooms. Aquat Microb Ecol 25:103-111

Submitted: November 11, 2001; Accepted: June 21, 2002

Proofs received from author(s): October 14, 2002 